\title{
Quebec plan may force doctors to work more
}

$\mathrm{Q}$ uebec Health Minister Dr. Gaétan Barrette is planning nothing less than remodelling the province's health care system by shedding a tier of administration and forcing doctors to work at least 12 hours a week in public facilities and have a caseload of at least 1000 patients or risk losing up to $30 \%$ of their pay.

Barrette has tabled two bills designed to save $\$ 270$ million and make the system more efficient. But critics say the impact of the bills has not been properly assessed and they give the minister too much power.

Bill 10, which was tabled in September, proposes cutting a whole level of administrative power in the health care system by ridding the province of its regional health agencies and service centres, and replacing them with Centres of Intervention of Health and Social Services. The number of administrative boards, including those for hospitals, mental institutions, nursing homes and other facilities would also be cut.

Overall, the number of health-related boards would drop from 182 to 19 ; in the process 1300 administrative positions would be eliminated. The minister hopes the move will save $\$ 220$ million per year.
Doctors, unions and patient organizations have criticized the bill, which was reportedly crafted without consulting them.

"The proposed network will look like a train with 19 wagons made in the same mold, with a single locomotive and one mechanic, the minister," said Dr. Charles Bernard, president and CEO of the Collège des médecins du Québec. "But where is this train going and where will it find the energy to keep it going?" he said in parliamentary committee.

On Nov. 28, Barrette tabled Bill 20, which is designed to increase access to patient care by forcing family doctors to have a minimum of 1000 patients on their rosters, and to work at least 12 hours a week at a hospital, long-term care centre or other public facility, depending on the needs in their region.

The bill also proposes cutting funding for in-vitro fertilization treatments, a move that would save the province nearly $\$ 50$ million annually.

"Bill 10 organizes care, Bill 20 increases healing," said Barrette. He said the combination of the two bills will resolve the problems of the Quebec health network and give 8 million Quebecers better access to a family doctor. According to Barrette, physicians in

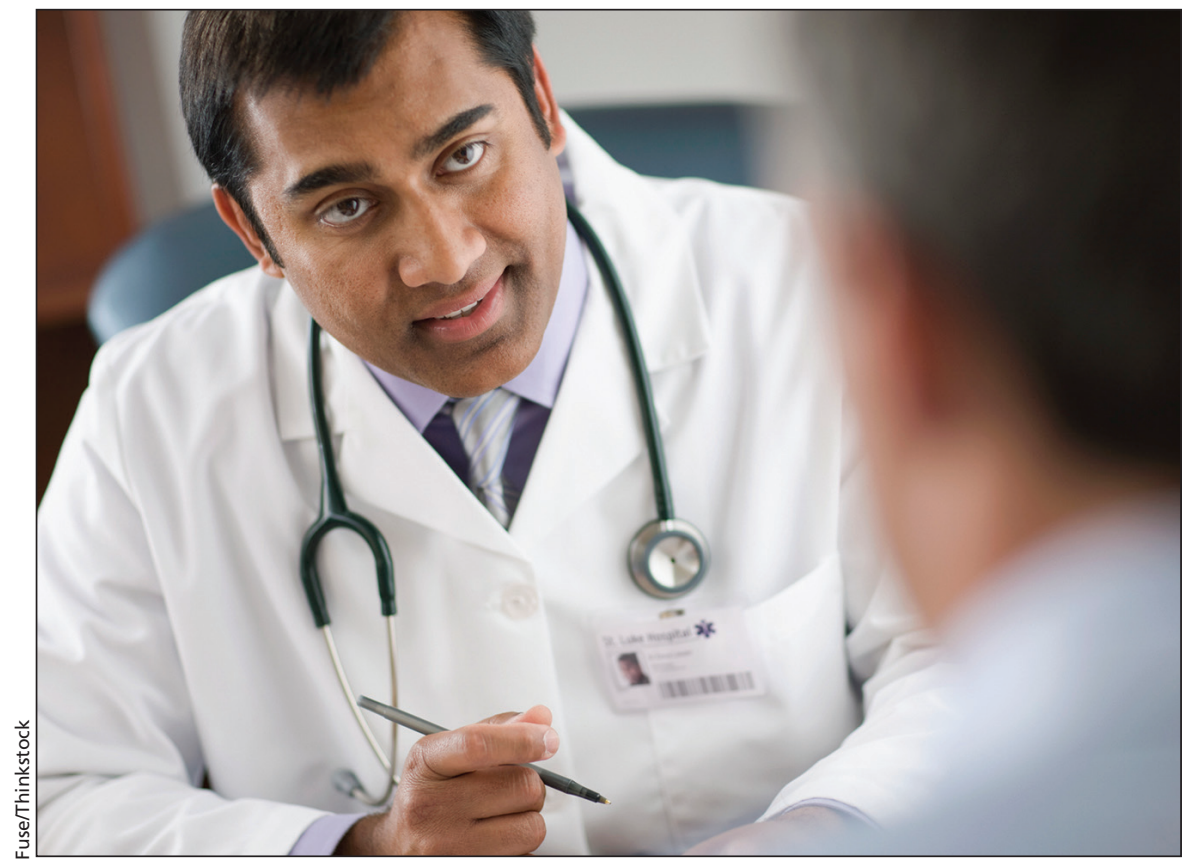

Two bills before the Quebec National Assembly would slash the number of health boards and force physicians to work a minimum number of hours in public institutions. other provinces see an average of 30 patients per day, while physicians in Quebec see 14. On average, a family doctor in Quebec has a caseload of 564 patients, Barrette said, meaning many people go to emergency departments for routine care.

"The Fédération des Médecins Omnipraticiens du Québec is stupefied and shocked by the contents of Bill 20," wrote Dr. Louis Godin, president of the group representing general practitioners, in a statement.

"It goes much further than just structural reform," said Jean-Pierre Ménard a lawyer who is known for defending patients' rights in Quebec. "It falls on transparency, independence and accountability of the network," he added in a letter to the minister.

More than 50 groups have asked the minister to scrap Bill 10, including unions, which says the new bills will undermine social services. President of the Confédération des syndicats nationaux, Jean Lacharité, said the proposed structure will undermine the unique social mission of Quebec's health services and "specifically hurt people with mental and intellectual challenges."

The father of social health care in Quebec, Claude Castonguay, also spoke out against the proposed reform in an open letter. According to the retired politician, these changes could eventually give private enterprises a bigger hold on the health care system and be detrimental to patients who will be further from the centre of decisions.

François Guérard, a health care historian at l'Université du Québec in Chicoutimi, estimates the Quebec health care system has not "undergone such remodelling since the Révolution tranquille," the Quiet Revolution of the 60s. He says that many fear it will be specifically detrimental to remote regions because it will centralize power in Québec City. "No one really knows the implication of such changes, and it is possible that even the minister does not know himself," he said in a phone interview. - Véronique Morin, Montréal, Que.

CMAJ 2015. DOI:10.1503/cmaj.109-4954 